\title{
Article
}

\section{In Vitro Activity of Several Essential Oils Extracted from Aromatic Plants against Ascosphaera apis}

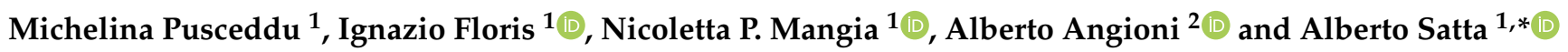 \\ 1 Department of Agricultural Sciences, University of Sassari, 07100 Sassari, Italy; \\ mpusceddu@uniss.it (M.P.); ifloris@uniss.it (I.F.); nmangia@uniss.it (N.P.M.) \\ 2 Department of Life and Environmental Sciences, University of Cagliari, 09124 Cagliari, Italy; \\ aangioni@unica.it \\ * Correspondence: albsatta@uniss.it; Tel.: +39-079-229364
}

Citation: Pusceddu, M.; Floris, I.;

Mangia, N.P.; Angioni, A.; Satta, A. In Vitro Activity of Several Essential Oils Extracted from Aromatic Plants against Ascosphaera apis. Vet. Sci. 2021, 8, 80. https://doi.org/10.3390/ vetsci 8050080

Academic Editor: Patrick Butaye

Received: 21 March 2021

Accepted: 6 May 2021

Published: 10 May 2021

Publisher's Note: MDPI stays neutral with regard to jurisdictional claims in published maps and institutional affiliations.

Copyright: (C) 2021 by the authors. Licensee MDPI, Basel, Switzerland. This article is an open access article distributed under the terms and conditions of the Creative Commons Attribution (CC BY) license (https:// creativecommons.org/licenses/by/ $4.0 /)$.

\begin{abstract}
The use of natural substances such as essentials oils against bee pathogens is of great interest as an alternative to traditional methods based on synthetic compounds like antibiotics and fungicides, in order to minimize the risk of having toxic residues in hive products and to prevent the development of resistance phenomena. This study evaluated the inhibitory, fungicidal and sporicidal activity of ten essential oils extracted from aromatic plants against Ascosphaera apis, the etiological agent of chalkbrood, an invasive honey bee mycosis. The most effective essential oils were Thymus herba-barona, Thymus capitatus and Cinnamomum zeylanicum, which showed values of minimum fungicidal concentration and minimum sporicidal concentration ranging from 200 to 400 ppm. Carvacrol was the main component of Thymus capitatus and Thymus herba-barona oils, whereas cinnamic aldehyde prevailed in Cinnamomum zeylanicum oil. Further in-apiary studies will allow the evaluation of side effects on bees and residues in hive products.
\end{abstract}

Keywords: chalkbrood; honey bee diseases; biological control; aromatic plants

\section{Introduction}

All the identified species of fungi belonging to the genus Ascosphaera (Ascomycota: Plectomycetes; Ascosphaearales) have been detected in bees [1,2]. The fungus Ascosphaera apis (Maassen ex Claussen) Olive and Spiltoir is the etiological agent of the invasive honey bee mycosis named chalkbrood [3]. It is a heterothallic organism that sporulates when mycelia of two different strains of the opposite sex touch each other and fruiting bodies are formed [4]. The disease transmission occurs through the ingestion of spores from contaminated food by the young bee larvae [5]. After infection, the larvae reduce their food consumption quickly until they stop eating [5]. Bee larvae in the fifth instar are the most sensitive to the disease, as they have favorable environmental conditions in their gut for spore germination [6-8]. Once in the larval gut, the spores are activated by $\mathrm{CO}_{2}$ obtained from the cells [9]. Then, they can germinate in the lumen, producing a mycelium which pierces the larval cuticle [9]. In this phase, the larvae look like tiny pieces of chalk or "mummies", which gives the name of chalkbrood to the disease $[7,10]$. As the disease progresses, the larvae become mummified, changing from white to a dark gray or black color due to the presence of spores on the larval cuticle $[10,11]$.

This fungal disease occurs widely in temperate regions and is most prevalent in the spring when there is an increase in the brood in the hive [12]. Fungal spores confined in wax and food stored inside the beehive are very resistant and remain infective for many years, providing a continuous source of infection $[7,11]$. The spread of $A$. apis infection in apiary can also be facilitated by its interaction with other pathogens or parasites such as the ectoparasite Varroa destructor [13,14]. In fact, the body surface of mites can become contaminated with fungal spores $[15,16]$, but doubts remain as to whether these can cause infection, since many spores would be required to contaminate the larval food and 
be ingested by the developing honey bee brood. This would preclude effective direct transmission of $A$. apis by mites. In addition, other factors, such as the genetic strain of the pathogen or the host, can influence the incidence and severity of the disease [17]. Although chalkbrood rarely leads to the collapse of the colonies, it can weaken the hives, with a consequent reduction in honey production and considerable economic losses [18]. The incidence of chalkbrood may be on the rise around the world [19].

Many different chemical compounds have been tested in order to control the chalkbrood disease [10,20-22], but no effective drugs against this fungal disease are currently available. When the colonies are infected, only a temporary reduction of symptoms has been achieved [22]. In fact, it is extremely difficult to eradicate this disease, because chemical products do not kill the spores, which are very persistent in the hive environment [11]. In addition, synthetic antifungal agents have several negative effects such as reductions in bee vitality in various life stages, an increase in resistance development and the contamination of hive products [23].

The use of natural substances in apiculture is of great interest because of the reduced risk of leaving harmful residues for human consumers [12,24]. One of the most tested groups of natural compounds against different honey bee diseases is represented by essential oils (EOs) [25], the antifungal activity of which is probably due to phenols and terpenic compounds [23]. The interest in testing essential oils as an alternative control strategy against $A$. apis has grown over the past years $[5,12,23,26-31]$.

Essential oils are hydrophobic liquids containing bioactive volatile compounds with high chemical variability [32], which complicates the study of their pharmacological power. In this work, we evaluated the in vitro activity of 10 essential oils from aromatic plants, most of them typical of the Mediterranean region, against A. apis, using the agar diffusion method. In addition, bioassays were performed to assess the minimum inhibitory concentration (MIC), the minimum fungicidal concentration (MFC) and the minimum sporicidal concentration (MSC) values (ppm) of the four essential oils, which showed inhibition haloes greater than that of nystatin (the positive control). They were also chemically characterized by means of gas chromatography-flame ionization detector (GC-FID) and gas chromatography-mass spectrometry analysis (GC-MS).

\section{Materials and Methods}

\subsection{Ascosphaera apis Culture and Inoculum Preparation}

The reference strain Ascosphaera apis 3116 used in this study was provided by the DMSZ collection (German Collection of Microorganism and Cell Cultures $\mathrm{GmbH}$ ). The strain was stored at $4{ }^{\circ} \mathrm{C}$ until microbiological tests. Fresh culture of $A$. apis was obtained by growing the fungus on a Sabouraud dextrose agar (SDA; Oxoid, Milan, Italy) at $30^{\circ} \mathrm{C}$ for 5 days in aerobic conditions, used as a stock plate. Fungal spores were obtained by exposing A. apis culture in Sabouraud dextrose broth (SDB) at a high level of $\mathrm{CO}_{2}$ and at $37^{\circ} \mathrm{C}$ for $4 \mathrm{~h}$ and then at $20^{\circ} \mathrm{C}$ for $72 \mathrm{~h}$. After microscopic enumeration with a cell-counting hemocytometer (Neubauer chamber; Merck, Milan, Italy), the spore concentration was adjusted to about $1 \times 10^{5}$ spores $/ \mathrm{mL}$ before final inoculation.

\subsection{Plant Collection and Essential Oil (EO) Preparation}

The following officinal plants were collected in 2017 during their flowering period in Sardinia (Italy): Thymus capitatus (L.) Hofimans and Link, Thymus herba-barona Loisel (endemic to Sardinia and Corsica), Rosmarinus officinalis (L.), Myrtus communis L., Eucalyptus globulus Labill., Salvia desoleana Atzei and Picci (endemic to Sardinia), Salvia officinalis (L.), and Helichrysum italicum subs. microphyllum G. Don. (endemic to Sardinia, Corsica, Balearic Islands and Crete). Moreover, we also tested two commercial essential oils provided by Cruciani (Rome, Italy), Cinnamomum zeylanicum and Rosmarinus officinalis. The former is known for its sporicidal activity against Paenibacillus larvae, the agent of the American foulbrood [33]. Flowering tops and stems of each of the eight species were collected from the plants at sunrise, stored immediately at a temperature below $24{ }^{\circ} \mathrm{C}$ and brought to the 
laboratory within $6 \mathrm{~h}$ after harvest for analysis. The distillation process was performed on homogeneous samples (same weight), without any pre-processing, in a 50-L steel steam distiller (Albrigi-Stallavena, Verona, Italy) with a recycling system for about $2 \mathrm{~h}$. At the end of distillation, the EOs, separated from water by decantation, were recovered directly from the distillate and dried over anhydrous $\mathrm{Na}_{2} \mathrm{SO}_{4}$ according to the method of Angioni et al. [33]. The oils were stored at $4{ }^{\circ} \mathrm{C}$ in the dark until use.

\subsection{Antifungal Test of Essential Oils (EOs) \\ 2.3.1. Agar Diffusion Method}

A first screening to establish the susceptibility of $A$. apis to EOs was carried out using the paper disc agar diffusion (PDD) method. From an SDA agar plate, a mycelium disc of $6 \mathrm{~mm}$ in diameter was taken, dissolved in Ringer solution (Oxoid) and vortexed for $5 \mathrm{~min}$. Subsequently, $1 \mathrm{~mL}$ of the fungal suspension was overlaid on the SDA plate. After plate solidification, sterile filter paper discs (6 mm in diameter, Oxoid, Milan, Italy), saturated with each pure essential oil $(n=10)$, were placed over the plate surface (PDD method). The cultures were then incubated at $30{ }^{\circ} \mathrm{C}$ for 5 days. Blank discs and synthetic antifungal nystatin were used as negative and positive controls, respectively. The diameter ( $\mathrm{mm}$ ) of fungal growth inhibition was measured (disk diameter included). An EO activity level higher than $20 \mathrm{~mm}$ was classified as high activity. All the experiments were carried out in triplicate for each essential oil.

\subsubsection{Microdilution Method}

In the second stage of the experiment, minimum inhibitory concentration (MIC), minimum fungicidal concentration (MFC) and minimum sporicidal concentration (MSC) values of the four essential oils which showed inhibition haloes greater than that of nystatin (the positive control), i.e., with a minimum halo diameter $>20 \mathrm{~mm}$, were determined using the microdilution method based on standard CLSI (2008) guidelines [34] with minor modifications.

Briefly, MIC determination was performed on a 96-well microtiter plate (Merk, Milan, Italy) containing SDB medium. The EOs were first diluted to obtain the highest concentration of 500 ppm, which was further diluted to obtain the following concentrations: 400, 300, 200, 100 and $50 \mathrm{ppm}$. The highest oil concentration used in our bioassays was based on previous tests evaluating the possible side effects of these oils on adult bees [35]. Each well was inoculated with a fungal suspension (obtained as described above) in such a volume as to obtain a concentration of about $106 \mathrm{CFU} / \mathrm{mL}$. Then, the microplates were kept at $30{ }^{\circ} \mathrm{C}$ for 5 days. The lowest concentration of the EOs in which there was no visible growth (i.e., the absence of turbidity in the well) was taken as the MIC [36].

Furthermore, in order to establish the MFC, the subcultures taken from the MIC wells where no visible growth was recorded were streaked on an SDA plate. After incubation at $30{ }^{\circ} \mathrm{C}$ for 5 days in aerobic conditions, the fungal viable growth was evaluated. The lowest concentration of the EOs in which there was no fungal growth was taken as the MFC. Finally, to evaluate the minimum sporicidal concentration (MSC), the same method was used; the microplates containing the EOs at different concentrations were inoculated with an aliquot of the fungal spores' culture (described above) and incubated at $30{ }^{\circ} \mathrm{C}$ for 5 days. An aliquot from the well, in which there was no visible growth, was taken and inoculated on an SDA plate. After incubation time, the lowest concentration of the EOs in which there was no viable growth on the SDA plate was taken as the MSC. All trials were made with three replications for each EO tested. Because the results were homogeneous in all three replicates, the values of MIC, MFC and MSC were reported in the table without a measure of variability. SDB medium without essential oils was used as a control.

\subsection{Chemical Composition}

The analytical standards (97\%) used for confirmation and quantification analysis were purchased from Extrasynthese (Genay, France) and Sigma Aldrich (Milan, Italy). 2,6-dimethylphenol was used as an internal standard (99.8\%; Sigma Aldrich, Milan, Italy). 
Solutions of $1 \%(w / v)$ oil were prepared in hexane for gas chromatography (GC) analysis. Quali-quantitative analyses of the EOs were performed in triplicate, obtained from independent distillation experiments.

The chemical composition of the oils was assessed using a gas chromatographyflame ionization detector (GC-FID) and gas chromatography-mass spectrometry (GC-MS) analysis. An HROC 5300 Mega series gas-chromatograph, coupled with an FID (Carlo Erba, Milan, Italy), was used for quantitative analysis, whereas a Hewlett Packard 5890 series II gas-chromatograph (Hewlett Packard, Avondale, PA), equipped with a HP $5971 \mathrm{~A}(70 \mathrm{eV})$ mass selective detector (MSD) in manual injection mode, a split-splitless injector and an MS ChemStation HP v. C.00.07, was used for peak identification and confirmation. The column was a fused silica capillary DB-5MS ( $5 \%$ phenylmethylpolysiloxane, $30 \mathrm{~m} \times 0.25 \mathrm{~mm}$ id, $0.25 \mu \mathrm{m}$ film thickness) (J\&W Scientific Fisons, Folsom, CA, USA). The injector and the interface were operated at $200{ }^{\circ} \mathrm{C}$ and $280^{\circ} \mathrm{C}$, respectively. The oven temperature was programmed as follows: from $60^{\circ} \mathrm{C}$ to $180{ }^{\circ} \mathrm{C}\left(3{ }^{\circ} \mathrm{C} / \mathrm{min}\right)$ and isothermally held for $15 \mathrm{~min}$. Helium was the carrier gas at $0.9 \mathrm{~mL} / \mathrm{min}$, and the sample $(1 \mu \mathrm{L})$ was injected in split mode (1:20). MS conditions were as follows: ionization voltage, $70 \mathrm{eV}$; scan rate, $1.6 \mathrm{scan} / \mathrm{s}$; mass range, $40-500$; and ion source temperature, $180^{\circ} \mathrm{C}$. The identification of the essential oil compounds was based on comparison of the retention times with those of authentic samples, comparing their linear retention index (LRI) relative to the series of n-hydrocarbons, and on computer matching against mass spectrum commercial libraries (NIST 98 and ADAMS) and a homemade library built up from pure substances and components of known oils and MS literature data.

\subsection{Statistical Analysis}

ANOVA was used to analyze the inhibition halo data after logarithmic transformation $(\log (1+x))$ to reduce the heterogeneity of the variance, checked using the Shapiro-Wilk test. When significant differences were detected, means were separated using the Tukey post-hoc test. Table 1 shows the untransformed values. All tests were carried out using $R$ software [37] implemented with the agricolae library.

Table 1. Inhibition halo diameter (mean $\pm \mathrm{SD}$ ) of pure essential oils on Ascosphaera apis using the paper disc agar diffusion assay.

\begin{tabular}{cc}
\hline Essential Oils & Inhibition Halo Diameter (mm) \\
\hline Thymus herba-barona & No growth \\
Thymus capitatus & No growth \\
Helichrysum italicum & $40.0 \pm 2.00 \mathrm{a}$ \\
Cinnamomum zeylanicum (commercial) & $24.8 \pm 0.76 \mathrm{~b}$ \\
Rosmarinus officinalis (commercial) & $16.0 \pm 1.32 \mathrm{c}$ \\
Eucalyptus globulus & $10.0 \pm 1.73 \mathrm{~d}$ \\
Rosmarinus officinalis & $9.0 \pm 1.00 \mathrm{~d}$ \\
Myrtus communis & $8.0 \pm 0.50 \mathrm{~d}$ \\
Salvia desoleana & No inhibition \\
Salvia officinalis & No inhibition \\
Nystatin & $17.0 \pm 1.32 \mathrm{c}$ \\
Control & No inhibition \\
\hline
\end{tabular}

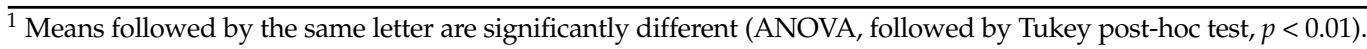

\section{Results}

Among the 10 pure essential oils tested against $A$. apis using the PDD method, the most effective were T. herba-barona and T. capitatus, which fully blocked the growth of the fungus (Table 1). On average, the essential oils from H. italicum and C. zeylanicum produced an inhibition halo of 40.0 and $24.8 \mathrm{~mm}$, respectively (Table 1). A lower inhibiting effect was observed for the oils from R. officinalis (commercial and non-commercial), E. globulus and $M$. communis plants, which showed an inhibition halo smaller than $16 \mathrm{~mm}$. S. desoleana and $S$. officinalis did not show any antimicrobial activity, as observed in the control plate. Nystatin 
showed a mean inhibition diameter of $17.0 \mathrm{~mm}$, similar to the commercial Rosmarinus and lower than Thymus, Helichrysum and C. zeylanicum (Table 1).

Based on the agar diffusion results, in which pure essential oils were employed, the microdilution assay and characterization analysis were conducted only on the four essential oils that showed the highest activity (inhibition halo diameters larger than $20 \mathrm{~mm}$ ). The assays on the vegetative forms performed in Sabouraud broth showed an inhibitory effect (MIC) on the growth of A. apis at $100 \mathrm{ppm}$ for T. capitatus and T. herba-barona oils and 200 ppm for Cinnamomum oil, whereas Helichrysum did not show any inhibitory activity even at the highest concentration (500 ppm) (Table 2). In the assays carried out in Sabouraud dextrose agar, Cinnamomum essential oil showed an MFC at 200 ppm, whereas both thyme oils demonstrated an MFC at 300 ppm (Table 2). In contrast, Helichrysum essential oil did not show any inhibition activity at any of the concentrations tested in this type of assay (Table 2). The inhibitory test carried out on the A. apis spores showed an overall high resistance of these forms to the essential oils. Only MSC values of $400 \mathrm{ppm}$ showed a sporicidal effect for both Thymus oils and the Cinnamomum oil, whereas Helichrysum required an MSC of $500 \mathrm{ppm}$ (Table 2). In all bioassays performed, we observed a regular growth of the fungus $A$. apis in the control treatment.

Table 2. Minimum inhibitory concentration (MIC), minimum fungicidal concentration (MFC) and minimum sporicidal concentration (MSC) values of the four pure essential oils that showed the highest activity against Ascosphaera apis in the preliminary agar diffusion tests.

\begin{tabular}{cccc}
\hline Essential Oils & $\begin{array}{c}\mathbf{M I C}^{\mathbf{1}} \\
(\boldsymbol{\mu g} / \mathbf{m L})\end{array}$ & $\begin{array}{c}\mathbf{M F C}^{\mathbf{2}} \\
(\boldsymbol{\mu g} / \mathbf{m L})\end{array}$ & $\begin{array}{c}\mathbf{M S C}^{2} \\
(\boldsymbol{\mu g} / \mathbf{m L})\end{array}$ \\
\hline Thymus capitatus & $100^{3}$ & 300 & 400 \\
Thymus herba-barona & 100 & 300 & 400 \\
Cinnamomum zeylanicum & 200 & 200 & 400 \\
Helichrysum italicum & - & - & 500 \\
\hline
\end{tabular}

${ }^{1}$ Bioassay performed in Sabouraud broth. ${ }^{2}$ Bioassay performed in Sabouraud dextrose agar. ${ }^{3}$ Values of MIC, MFC and MSC are reported without measures of variability because they were homogeneous in all three replicates.

The GC-MS analysis allowed the identification of 20 compounds in thyme samples. The main component of thyme essential oils was carvacrol $(68.0 \%$ for T. capitatus and $60.0 \%$ for $T$. herba-barona), followed by $\gamma$-terpinene, $p$-cymene, $\beta$-cariophyllene and $\beta$ myrcene. Cinnamomum essential oil showed 22 compounds, but it was constituted mainly of cinnamic aldehyde $(79.3 \%)$ and eugenol $(11.9 \%)$, with the amounts other compounds below $0.5 \%$, except for $\alpha$-pinene (1.8\%) and $\alpha$-thujene (1.1\%). Helichrysum essential oil showed 24 identified compounds, with the main compounds derived from the nerol series. Neryl acetate was the main compound, accounting for $51.6 \%$, followed by nerol $(8.22 \%)$ and neryl propionate (5.51\%). $\beta$-Eudesmol, $\gamma$-curcumene, limonene, $\alpha$-terpineol, linalyl acetate and $\alpha$-eudesmol showed values ranging between $1.06 \%$ and $2.27 \%$, whereas curcumene and linalool showed values below $5 \%$ (Table 3 ).

Table 3. Chemical characterization $(\% w / w)$ of the essential oils that showed the highest activity against Ascosphaera apis by means of gas chromatography-flame ionization detector (GC/FID) and gas chromatography-mass spectrometry analysis (GC/MS).

\begin{tabular}{|c|c|c|c|c|c|c|}
\hline \multirow[b]{2}{*}{ Components } & \multirow[b]{2}{*}{ CAS Number } & \multirow[b]{2}{*}{$\begin{array}{l}\text { r.t. } \\
\min \end{array}$} & \multicolumn{4}{|c|}{ Essential Oils } \\
\hline & & & $\begin{array}{c}\text { Thymus } \\
\text { capitatus }\end{array}$ & $\begin{array}{c}\text { Thymus } \\
\text { herba-barona }\end{array}$ & $\begin{array}{c}\text { Cinnamomun } \\
\text { zeylanicum }\end{array}$ & $\begin{array}{c}\text { Helichrysum } \\
\text { italicum }\end{array}$ \\
\hline unknown & & 5.25 & $-\beta$ & 1.95 & - & 0.56 \\
\hline$\alpha$-Thujene & $2867-05-2$ & 5.76 & 1.60 & 1.00 & 1.1 & - \\
\hline$\alpha$-Pinene & $7785-26-4$ & 6.13 & 0.72 & 0.31 & 1.8 & 0.44 \\
\hline Camphene & $79-92-5$ & 7.17 & 0.22 & 0.50 & 0.2 & 0.27 \\
\hline Benzaldehyde & $100-52-7$ & 7.30 & - & - & 0.2 & - \\
\hline Sabinene & $3387-41-5$ & 7.50 & - & - & - & - \\
\hline
\end{tabular}


Table 3. Cont.

\begin{tabular}{|c|c|c|c|c|c|c|}
\hline \multirow[b]{2}{*}{ Components } & \multirow[b]{2}{*}{ CAS Number } & \multirow{2}{*}{$\begin{array}{l}\text { r.t. } \\
\min \end{array}$} & \multicolumn{4}{|c|}{ Essential Oils } \\
\hline & & & $\begin{array}{l}\text { Thymus } \\
\text { capitatus }\end{array}$ & $\begin{array}{c}\text { Thymus } \\
\text { herba-barona }\end{array}$ & $\begin{array}{l}\text { Cinnamomun } \\
\text { zeylanicum }\end{array}$ & $\begin{array}{c}\text { Helichrysum } \\
\text { italicum }\end{array}$ \\
\hline$\beta$-Pinene & $127-91-3$ & 7.88 & 0.08 & 2.23 & 0.1 & 0.20 \\
\hline$\Delta^{3}$-Carene & $13466-78-9$ & 9.10 & 1.54 & - & - & - \\
\hline$\beta$-Mircene & $123-35-3$ & 9.14 & 2.11 & 1.05 & - & 0.27 \\
\hline$\alpha$-Phellandrene & $2243-33-6$ & 9.30 & 0.10 & 0.18 & 0.1 & 0.19 \\
\hline$\alpha$-Terpinene & $99-86-5$ & 9.57 & n.d. $\gamma$ & 1.04 & - & - \\
\hline Limonene & $138-86-3$ & 10.28 & 0.97 & - & 0.2 & 1.71 \\
\hline p-Cymene & $99-87-6$ & 10.34 & 6.17 & 6.16 & 0.2 & 0.15 \\
\hline 1.8-Cineolo & $470-82-6$ & 10.71 & - & 0.96 & - & 0.83 \\
\hline$\gamma$-Terpinene & $99-85-4$ & 11.80 & 6.33 & 4.49 & - & 0.13 \\
\hline Terpinolene & $586-62-9$ & 12.75 & 1.15 & 0.20 & - & - \\
\hline Cinnamic aldehyde & $104-55-2$ & 14.72 & - & - & 79.3 & - \\
\hline Terpinil acetate & $80-26-2$ & 22.53 & - & - & - & 0.39 \\
\hline Geranyl acetate & $105-87-3$ & 22.70 & - & - & - & 0.13 \\
\hline Camphor & $76-22-2$ & 23.59 & - & - & 0.1 & - \\
\hline Linalool & $78-70-6$ & 23.71 & n.d. & 1.96 & 0.5 & 5.34 \\
\hline 3-Octanol & $589-98-0$ & 23.82 & 0.32 & - & - & - \\
\hline$\alpha$-Thujone & $546-80-5$ & 23.98 & - & - & - & - \\
\hline$\beta$-Thujone & $471-15-8$ & 24.10 & - & - & - & - \\
\hline Bornyl acetate & $5655-61-8$ & 24.39 & 0.04 & - & 0.5 & - \\
\hline Farnesol & $4602-84-0$ & 24.45 & - & - & 0.2 & - \\
\hline Linalyl acetate & $115-95-7$ & 24.51 & - & - & - & 1.47 \\
\hline$\beta$-Caryophyllene & $87-44-5$ & 24.66 & 5.20 & 2.04 & 0.1 & 0.44 \\
\hline Linalyl isobutirrate & $78-35-3$ & 25.21 & - & - & 0.1 & - \\
\hline Terpinen-4-ol & $562-74-3$ & 25.52 & 0.22 & 1.26 & - & - \\
\hline$\gamma$-Curcumene & $28976-68-3$ & 27.50 & - & - & - & 2.05 \\
\hline Curcumene & $644-30-4$ & 27.65 & - & - & - & 6.23 \\
\hline$\alpha$-Terpineol & $98-55-5$ & 28.89 & 0.07 & 0.13 & 0.2 & 1.58 \\
\hline Borneol & $464-45-9$ & 29.11 & n.d. & 4.25 & 0.2 & - \\
\hline Verbenone & 1196-01-6 & 29.60 & - & - & - & - \\
\hline$\beta$-Bisabolene & 495-61-4 & 26.93 & - & - & - & - \\
\hline Carvone & $2244-16-8$ & 30.13 & - & 0.84 & - & - \\
\hline Nerol & $106-25-2$ & 32.65 & - & - & - & 8.22 \\
\hline Neryl acetate & $141-12-8$ & 33.89 & - & - & - & 51.59 \\
\hline Geraniol & $106-24-1$ & 34.27 & - & - & 0.2 & - \\
\hline Caryophyllene oxide & $1139-30-6$ & 38.41 & 0.22 & 1.23 & - & - \\
\hline Metileugenol & $95-15-2$ & 39.44 & - & - & 0.3 & - \\
\hline Neryl propionate & $105-91-9$ & 40.12 & - & - & - & 5.51 \\
\hline Eugenol & $97-53-0$ & 41.01 & - & - & 11.9 & - \\
\hline$\beta$-Eudesmol & $473-15-4$ & 42.15 & - & - & - & 2.27 \\
\hline$\alpha$-Eudesmol & $473-16-5$ & 42.89 & - & - & - & 1.06 \\
\hline Cinnamyl alcohol & $104-54-1$ & 44.03 & - & - & 0.5 & - \\
\hline Thymol & $89-83-8$ & 44.59 & 0.38 & 1.48 & - & 0.16 \\
\hline Carvacrol & $499-75-2$ & 45.47 & 68.01 & 60.04 & - & 0.13 \\
\hline
\end{tabular}

${ }^{\alpha}$ retention time. ${ }^{\beta}$ " ${ }_{-}$indicates that the compound was searched for but not detected in the EO. $\gamma$ "n.d." indicates that the compound was searched for and detected but was below the quantification limit.

\section{Discussion}

Among the various essential oils tested in this study, mostly from Mediterranean aromatic plants, the main finding was the higher efficacy of Thymus capitatus, Thymus herba-barona, Cinnamomum zeylanicum and Helichrysum italicum oils compared to nystatin, a common antimycotic drug. Furthermore, C. zeylanicum, T. herba-barona and T. capitata oils displayed the best fungicidal and sporicidal action, and their potential use in controlling infection in apiaries should be taken into consideration. Although previous in vitro studies have focused mainly on the fungicidal and non-sporicidal effects of essential oils, the observed sporicidal effect is very important because it suggests that some oils could be employed in the disinfection of combs or beekeeping equipment.

The antifungal activity of the Thymus vulgaris essential oil against $A$. apis was tested in previous studies using the agar dilution method [28,38]. Subsequently, T. vulgaris was confirmed to be a strong inhibitor of mycelium growth in the vapor phase as well $[12,23]$. This bioactivity is attributable to two phenolic monoterpenes, thymol and carvacrol, which 
are major bioactive components of Thymus oil [31]. This was confirmed in our bioassays, where carvacrol was identified as the major component of Thymus capitatus oil $(68 \%)$ and Thymus herba-barona oil (60\%), although thymol was present in small amounts.

Several products based on thymol are already commercially available against the ectoparasite mite Varroa destructor and are used inside hives [39]. An important advantage of beehive treatments with thymol is that no maximum residue limit in honey is imposed for this compound and no mite resistance against it has been found yet [39]. Furthermore, as it is highly volatile and apolar, thymol has a low persistence in honey compared to wax [39]. However, in bee wax, thymol residues can persist for several months [40]. In addition, thymol has negative effects on colony expansion, as it reduces the bee brood [39] and can affect phototaxis in treated bees but has no effects on colony mortality [41].

Our results confirm the excellent antimicrobic properties of Cinnamomum oil, already successfully applied in vitro and in vivo against Paenibacillus larvae [35,42-44], the ethiological agent of the american foulbrood, and against $A$. apis using both contact-dependent and contact-independent methods [30]. E-cinnamaldehyde was the major component present in the Cinnamomum oil used in our bioassays (79.3\%). In addition to both thymol and carvacrol, E-cinnamaldehyde and other compounds (citral, citronellal, geraniol, eugenol and borneol) have been reported to have significant inhibitory effects on fungal growth $[22,23,30,45]$. Because honey bees produce secretions containing geraniol, citral, geranic and nerolic acids through the Nasonov glands, the use of these natural substances that are already present in the nest may not disturb the colony [46-48]. Moreover, many of these volatile and extractable compounds detected in the analyzed essential oils can be found in wax [49], honey [50] and in resins collected from plants and used to produce propolis by bees [51,52]. Therefore, it is plausible to expect an endogenous inhibitory action of all these compounds characteristic of the hive environment on this pathogen. In support of this hypothesis, we know that the presence of some pathogens and/or parasites, including A. apis, in the hive triggers an increase in the resin collection by foragers $[53,54]$. However, toxicological studies on the lethal or sublethal effects of essential oils on treated bees are very few. The studies by Eguaras et al. [28] and Ruffinengo et al. [25] did not show toxicity (mortality) in bees treated with Tagetes minuta and Cinnamomun oils, respectively. These results are encouraging and future studies on the application and effects of these essential oils in apiaries are needed.

Studies like ours underline the importance of seeking more natural products such as essential oils to counteract beehive diseases, because they reduce the risk of the contamination of bee products and resistance phenomena due to pathogens or parasites. Furthermore, the high volatility of essential oils makes them suitable for application in closed environments, such as hives. Finally, natural pesticides are biodegradable compared to the long persistence of synthetic pesticides in the environment [55].

Natural antibiotics based on essential oils may represent an alternative to chemically synthesized antibiotics. However, the transition from laboratory results to the application of a commercial formulation in the field is difficult for several reasons-the variable availability of the plant material, the variability of the oil from the same plant species due to different geographical origins or strains, and the different extraction or application methods used [56].

In conclusion, our in vitro study showed promising results regarding the use of essential oils from Mediterranean garrigue plants, especially T. herba-barona and T. capitata, and commercial Cinnamomum zeylanicum oil in the control of Ascosphaera apis. The advantages and disadvantages of the potential use of essential oils were also analyzed, and these require further elucidation. Therefore, it would be useful to conduct in vivo experiments in order to perform an in-depth evaluation of the effects of these oils on bees and on bee product residues.

Author Contributions: Conceptualization, M.P., I.F. and A.S.; investigation and data curation, A.A., N.P.M. and M.P., writing — original draft preparation, I.F., M.P., and A.S.; writing-review and editing, A.A. and N.P.M. All authors have read and agreed to the published version of the manuscript. 
Funding: This research was funded by University of Sassari, FAR2020SATTA.

Institutional Review Board Statement: Not applicable.

Informed Consent Statement: Not applicable.

Data Availability Statement: Derived data supporting the findings of this study are available from the corresponding author [AS] on request.

Acknowledgments: The authors are grateful to Ana Helena Dias Francesconi for revising the manuscript.

Conflicts of Interest: The authors declare no conflict of interest. The funders had no role in the design of the study; in the collection, analyses, or interpretation of data; in the writing of the manuscript, or in the decision to publish the results.

\section{References}

1. Bissett, J.; Duke, G.; Goettel, M. Ascosphaera acerosa sp. nov. isolated from the alfalfa leafcutting bee, with a key to the species of Ascosphaera. Mycologia 1996, 88, 797-803. [CrossRef]

2. Youssef, N.N.; McManus, W.R. Ascosphaera torchioi sp. nov., a pathogen of Osmia lignaria propinqua (Hymenoptera). Mycotaxon 2001, 77, 7-13.

3. Spiltoir, C.F. Life cycle of Ascosphaera apis (Pericystis apis). Am. J. Bot. 1955, 42, 501-508. [CrossRef]

4. Aronstein, K.A.; Murray, K.D.; de León, J.H.; Qin, X.; Weinstock, G. High mobility group (HMG-box) genes in the honeybee fungal pathogen Ascosphaera apis. Mycologia 2007, 99, 553-561. [CrossRef] [PubMed]

5. Ansari, M.J.; Al-Ghamdi, A.; Usmani, S.; Khan, K.A.; Alqarni, A.S.; Kaur, M.; Al-Waili, N. In vitro evaluation of the effects of some plant essential oils on Ascosphaera apis, the causative agent of Chalkbrood disease. Saudi J. Biol. Sci. 2017, 24, 1001-1006. [CrossRef] [PubMed]

6. Bignell, D.E.; Heath, L.A.F. Electropositive redox state of the fifth-instar larval gut of Apis mellifera. J. Apic. Res. 1985, 24, 211-213. [CrossRef]

7. Puerta, F.; Flores, J.M.; Bustos, M.; Padilla, F.; Campano, F. Chalkbrood development in honeybee brood under controlled conditions. Apidologie 1994, 25, 540-546. [CrossRef]

8. Flores, J.M.; Ruiz, J.A.; Ruz, J.M.; Puerta, F.; Bustos, M.; Padilla, F.; Campano, F. Effect of temperature and humidity of sealed brood on chalkbrood development under controlled conditions. Apidologie 1996, 27, 185-192. [CrossRef]

9. Heath, L.A.F.; Gaze, B.M. Carbon dioxide activation of spores of the chalkbrood fungus Ascosphaera apis. J. Apic. Res. 1987, 26, 243-246. [CrossRef]

10. Heath, L.A.F. Chalk brood pathogens: A review. Bee World 1982, 63, 130-135. [CrossRef]

11. Bailey, L.; Ball, B.V. Honey Bee Pathology, 2nd ed.; Academic Press: London, UK, 1991; pp. 53-63.

12. Boudegga, H.; Boughalleb, N.; Barbouche, N.; Ben Hamouda, M.H.; El Mahjoub, M. In vitro inhibitory actions of some essential oils on Ascosphaera apis, a fungus responsible for honey bee chalkbrood. J. Apic. Res. 2010, 49, 236-242. [CrossRef]

13. Glinski, Z. The effect of Varroa jacobsoni Oud. on the incidence and course of chalkbrood disease in Apis mellifera L. colonies. Ann. Univ. Mariae Curie-Skłodowska Sect. DD Med. Vet. 1988, 43, 23-27.

14. Koch, W.; Ritter, W. Examination of artificially infested brood with Varroa mites for secondary infections. Apidologie 1989, 20, 517-519.

15. Liu, T.P.; Ritter, W. Morphology of some microorganisms associated with the female mite Varroa jacobsoni: A survey by electron microscopy. In Africanized Honey Bees and Bee Mites; Needham, G.R., Page, E., Jr., Delfinado-Baker, M., Bowman, C.E., Eds.; Ellis Horwood Ltd.: Chichester, UK, 1988; pp. 467-474.

16. Puerta, F.; Flores, J.K.; Jimenez, A.J.; Bustos, M.; Padilla, F. Enfermedades secundarias a la parasitación por Varroa en Apis mellifera. Vida Apic. 1990, 43, 54-59.

17. Flores, J.M.; Spivak, M.; Gutiérrez, I. Spores of Ascosphaera apis contained in wax foundation can infect honeybee brood. Vet. Microbiol. 2005, 108, 141-144. [CrossRef] [PubMed]

18. Zaghloul, O.A.; Mourad, A.K.; El Kady, M.B.; Nemat, F.M.; Morsy, M.E. Assessment of losses in honey yield due to the chalkbrood disease, with reference to the determination of its economic injury levels in Egypt. Commun. Agri. Appl. Biol. Sci. 2005, 70, 703-714.

19. Aronstein, K.A.; Murray, K.D. Chalkbrood disease in honey bees. J. Invertebr. Pathol. 2010, 103 (Suppl. 1), S20-S29. [CrossRef]

20. Liu, T.P. Effects of itraconazole on the sporocysts wall of the entomopathogenic fungi Ascosphaera apis as revealed by the scanning electron microscope. Mycopathologia 1988, 103, 75-80. [CrossRef]

21. Glinski, Z.; Chmielewski, M. Imidazole derivatives in control of the honey bee brood mycoses. Pszczel. Zesz. Nauk. 1996, 40, 163-173.

22. Davis, C.; Ward, W. Control of Chalkbrood Disease with Natural Products; RIRDC Publication No 03/2017; Rural Industries Research and Development Corporation, Canprint: Barton, Australia, 2003.

23. Kloucek, P.; Smid, J.; Flesar, J.; Havlik, J.; Titera, D.; Rada, V.; Drabek, O.; Kokoska, L. In vitro inhibitory activity of essential oil vapors against Ascosphaera apis. Nat. Prod. Commun. 2012, 7, 253-256. [CrossRef] 
24. Mourad, A.K.; Zaghloul, O.A.; El Kady, M.B.; Nemat, F.M.; Morsy, M.E. A novel approach for the management of the chalkbrood disease infesting honeybee Apis mellifera L. (Hymenoptera: Apidae) colonies in Egypt. Commun. Agric. Appl. Biol. Sci. 2005, 70, 601-611. [PubMed]

25. Ruffinengo, S.R.; Maggi, M.; Fuselli, S.; Floris, I.; Clemente, G.; Firpo, N.H.; Bailac, P.N.; Ponzi, M.I. Laboratory evaluation of Heterothalamus alienus essential oil against different pests of Apis mellifera. J. Essent. Oil Res. 2006, 18, 704-707. [CrossRef]

26. Larrán, S.; Ringuelet, J.A.; Carranza, M.R.; Henning, C.P.; Ré, M.S.; Cerimele, E.L.; Urrutia, M.I. In vitro fungistatic effect of essential oils against Ascosphaera apis. J. Essent. Oil Res. 2001, 13, 122-124. [CrossRef]

27. Dellacasa, A.D.; Bailac, P.N.; Ponzi, M.I.; Ruffinengo, S.R.; Eguaras, M.J. In Vitro activity of essential oils from San Luis-Argentina against Ascosphaera apis. J. Essent. Oil Res. 2003, 15, 282-285. [CrossRef]

28. Eguaras, M.J.; Fuselli, S.; Gende, L.; Fritz, R.; Ruffinengo, S.R.; Clemente, G.; Gonzalez, A.; Bailac, P.N.; Ponzi, M.I. An in vitro evaluation of Tagetes minuta essential oil for the control of the honeybee pathogens Paenibacillus larvae and Ascosphaera apis, and the parasitic mite Varroa destructor. J. Essent. Oil Res. 2005, 17, 336-340. [CrossRef]

29. Bailac, P.N.; Gende, L.; Gascón, A.; Fritz, R.; Ponzil, M.I.; Eguaras, M. Control of Ascosphaera apis and Paenibacillus larvae subsp. larvae by the use of essential oils for obtaining beehive products without toxic residues. Mol. Med. Chem. 2006, 11, 1-2.

30. Gabriel, K.T.; Kartforosh, L.; Crow, S.A., Jr.; Cornelison, C.T. Antimicrobial activity of essential oils against the fungal pathogens Ascosphaera apis and Pseudogymnoascus destructans. Mycopathologia 2018, 183, 921-934. [CrossRef]

31. Nardoni, S.; D'Ascenzi, C.; Rocchigiani, G.; Papini, R.A.; Pistelli, L.; Formato, G.; Najar, B.; Mancianti, F. Stonebrood and chalkbrood in Apis mellifera causing fungi: In Vitro sensitivity to some essential oils. Nat. Prod. Res. 2018, 32, 385-390. [CrossRef]

32. Barra, A. Factors affecting chemical variability of essential oils: A review of recent developments. Nat. Prod. Commun. 2009, 4, 1147-1154. [CrossRef]

33. Angioni, A.; Barra, A.; Arlorio, M.; Caisson, J.D.; Russo, M.T.; Pirisi, F.M.; Satta, M.; Cabras, P. Chemical Composition, Plant Genetic Differences, and Antifungal Activity of the Essential Oil of Helichrysum italicum G. Don ssp. microphyllum (Willd) Nym. J. Agric. Food Chem. 2003, 51, 1030-1034. [CrossRef]

34. Clinical and Laboratory Standards Institute. Reference Method for Broth Dilution Antifungal Susceptibility Testing of Filamentous Fungi, 2nd ed.; Approved Standard; Clinical and Laboratory Standards Institute: Wayne, PA, USA, 2008.

35. Floris, I.; Carta, C.; Moretti, M.D.L. Activités in vitro de plusieurs huiles essentielles sur Bacillus larvae White et essai au rucher. Apidologie 1996, 27, 111-119. [CrossRef]

36. Perczak, A.; Gwiazdowska, D.; Marchwińska, K.; Juś, K.; Gwiazdowski, R.; Waśkiewicz, A. Antifungal activity of selected essential oils against Fusarium culmorum and F. graminearum and their secondary metabolites in wheat seeds. Arch. Microbiol. 2019, 201, 1085-1097. [CrossRef]

37. R Core Team. R: A Language and Environment for Statistical Computing. R Foundation for Statistical Computing. 2018. Available online: http:/ / www.R-project.org (accessed on 15 February 2021).

38. Colin, M.E.; de Lahitte, J.D.; Larribau, E.; Boué, T. Activité des huiles essentielles de Labiées sur Ascophaera apis et traitement d'un rucher. Apidologie 1989, 20, 221-228. [CrossRef]

39. Floris, I.; Satta, A.; Cabras, P.; Garau, V.L.; Angioni, A. Comparison between two thymol formulations in the control of Varroa destructor: Effectiveness, persistence, and residues. J. Econ. Entomol. 2004, 97, 187-191. [CrossRef]

40. Carayon, J.L.; Téné, N.; Bonnafé, E.; Alayrangues, J.; Hotier, L.; Armengaud, C.; Treilhou, M. Thymol as an alternative to pesticides: Persistence and effects of Apilife Var on the phototactic behavior of the honeybee Apis mellifera. Environ. Sci. Pollut. Res. Int. 2014, 21, 4934-4939. [CrossRef]

41. Alayrangues, J.; Hotier, L.; Massou, I.; Bertrand, Y.; Armengaud, C. Prolonged effects of in-hive monoterpenoids on the honey bee Apis mellifera. Ecotoxicology 2016, 25, 856-862. [CrossRef]

42. Gende, L.B.; Floris, I.; Fritz, R.; Eguaras, M.J. Antimicrobial activity of cinnamon (Cinnamomum zeylanicum) essential oil and its main components against Paenibacillus larvae from Argentine. Bull. Insectology 2008, 61, 1-4.

43. Gende, L.B.; Maggi, M.D.; Damiani, N.; Fritz, R.; Eguaras, M.J.; Floris, I. Advances in the apiary control of the honeybee American Foulbrood with Cinnamon (Cinnamomum zeylanicum) essential oil. Bull. Insectology 2009, 62, 93-97.

44. Gende, L.B.; Fernandez, N.; Buffa, F.; Ruiu, L.; Satta, A.; Fritz, R.; Eguaras, M.J.; Floris, I. Susceptibility of Paenibacillus larvae isolates to a tetracycline hydrochloride and Cinnamon (Cinnamomum zeylanicum) essential oil mixture. Bull. Insectology 2010, 63, 247-250.

45. Calderone, N.W.; Shimanuki, H.; Allen-Wardell, G. An in vitro evaluation of botanical compounds for the control of the honeybee pathogens Bacillus larvae and Ascosphaera apis, and the secondary invader B. alvei. J. Essent. Oil Res. 1994, 6, 279-287. [CrossRef]

46. Boch, R.; Shearer, D.A. Identification of geraniol as the active component in the Nassanoff pheromone of the honey bee. Nature 1962, 194, 704-706. [CrossRef]

47. Boch, R.; Shearer, D.A. Identification of nerolic and geranic acids in the Nassanoff pheromone of the honey bee. Nature 1964, 202, 320-321. [CrossRef]

48. Shearer, D.A.; Boch, R. Citral in the Nassanoff pheromone of the honey bee. J. Insect Physiol. 1966, 12, 1513-1521. [CrossRef]

49. Felicioli, A.; Cilia, G.; Mancini, S.; Turchi, B.; Galaverna, G.; Cirlini, M.; Cerri, D.; Fratini, F. In vitro antibacterial activity and volatile characterisation of organic Apis mellifera ligustica (Spinola, 1906) beeswax ethanol extracts. Food Biosci. 2019, 29, 102-109. [CrossRef] 
50. Manyi-Loh, C.E.; Ndip, R.N.; Clarke, A.M. Volatile compounds in honey: A review on their involvement in aroma, botanical origin determination and potential biomedical activities. Int. J. Mol. Sci. 2011, 12, 9514-9532. [CrossRef] [PubMed]

51. Marcucci, M.C. Propolis: Chemical composition, biological properties and therapeutic activity. Apidologie 1995, 26, 83-99. [CrossRef]

52. Bankova, V.S.; de Castro, S.L.; Marcucci, M.C. Propolis: Recent advances in chemistry and plant origin. Apidologie 2000, $31,3-15$. [CrossRef]

53. Simone-Finstrom, M.D.; Spivak, M. Increased resin collection after parasite challenge: A case of self-medication in honey bees? PLoS ONE 2012, 7, e34601. [CrossRef] [PubMed]

54. Pusceddu, M.; Piluzza, G.; Theodorou, P.; Buffa, F.; Ruiu, L.; Bullitta, S.; Floris, I.; Satta, A. Resin foraging dynamics in Varroa destructor-infested hives: A case of medication of kin? Insect Sci. 2019, 26, 297-310. [CrossRef]

55. Guleria, S.; Tiku, A.K. Botanicals in pest management: Current status and future perspectives. In Integrated Pest Management: Innovation-Development Process; Peshin, R., Dhawan, A.K., Eds.; Springer Science + Business Media: Dordrecht, The Netherlands, 2009; Volume 1, pp. 317-329.

56. Koul, O.; Walia, S.; Dhaliwal, G.S. Essential oils as green pesticides: Potential and constraints. Biopestic Int. 2008, 4, 63-84. 